\title{
Influence of Nitrogen on Economics of Medium duration Rice Varieties
}

\author{
S. Sivaleela*, Manukonda Srinivas, Ch. Pulla Rao and A. Sireesha \\ Department of Agronomy, Agricultural College, Acharya N. G. Ranga Agricultural \\ University, Bapatla, Andhra Pradesh - 522101, India \\ *Corresponding author
}

\section{A B S T R A C T}

Ke y w o r d s
Recommended dose
of nitrogen,
Medium duration
varieties and
economics

\section{Introduction}

Rice (Oryza sativa) attains second place among cereal crops, both for acreage and production in the world (Siddiq et al., 2011). It is staple food for more than half of the world's population and plays an important role in food security. More than 90 per cent of rice is produced and consumed in Asian countries. Area sown for rice is estimated at $43.39 \mathrm{M}$ ha, with annual production of $104.32 \mathrm{~m} \mathrm{t}$ and productivity of $2.4 \mathrm{t} \mathrm{ha}^{-1}$. In Andhra Pradesh, rice is cultivated in an area of $2.16 \mathrm{M}$ ha with an annual production of $7.49 \mathrm{M} \mathrm{t}$ and productivity of $3.4 \mathrm{t} \mathrm{ha}^{-1}$ (Anonymous, 2016).
Fertilizer is one of the most efficient means of increasing rice. Balanced fertilization right from the very beginning of crop growth is utmost essential to achieve better harvest of crop (Singh and Namdeo, 2004). Nitrogen is the key nutrient that limits crop growth of cereals in many production systems. Nutrient requirement may however vary for based on duration of crop. The introduction of high yielding varieties of crops and utilization of various chemical fertilizers has brought a revolution in crop production. In India, medium duration rice cultivars gave maximum value on grain yield and its components, compared with short duration varieties. The yield potential of medium duration rice 
varieties is high because, they have more periods for growth and accumulation of biomass. The nutrient uptake is also high because, of its higher biomass production (Prasad and Prasad, 1980). Higher levels of nitrogen are needed for high yielding under medium and long duration varieties. Although, the total rice production has remained stable for last ten years due to unsystematic use of chemical fertilizers in Godavari region. The application of fertilizer in proper amounts must be done to boost up agricultural production to an economically desirable level (Punauallh et al., 1998). Fertilizer recommendations for crops in a cropping pattern needs change after a certain period of time with the advancement of research on fertilizer management in the country. A little information is only available on the performance of medium duration rice varieties in coastal Andhra Pradesh and its response to higher levels of nitrogen. A Hence, the present investigation was formulated to find out suitable combination of high yielding variety with appropriate dose of nitrogen for obtaining maximum and consistent yields in rice.

\section{Materials and Methods}

To ascertain the nitrogen requirement of medium duration rice varieties a field experiment was conducted during kharif season of 2017-2018 at Regional Agricultural Research Station, Marteru situated at $82^{\circ} 30^{\prime} \mathrm{E}$ longitude, $18^{\circ} 20^{\prime} \mathrm{N}$ latitude with an altitude of $5 \mathrm{~m}$ above MSL. The weekly mean maximum and minimum temperatures during the crop growth period were $30.02^{\circ} \mathrm{C}$ and $25.04^{\circ} \mathrm{C}$ respectively. The weekly mean average relative humidity at $8.30 \mathrm{hrs}$ was 86.10 per cent and at 17.30 hrs was 75.60 per cent. A total rainfall of $777.8 \mathrm{~mm}$ was received in 49 rainy days during the crop growth period. The crop was transplanted with a spacing of $20 \times$ $15 \mathrm{~cm}$. The soil was clay loam in texture having a $\mathrm{P}^{\mathrm{H}}$ of 6.74 , low in available nitrogen $\left(280 \mathrm{~kg} \mathrm{ha}^{-1}\right)$, medium in available phosphorus $\left(23 \mathrm{~kg} \mathrm{ha}^{-1}\right)$ and high in available potassium $\left(336 \mathrm{~kg} \mathrm{ha}^{-1}\right)$. The experiment was laid out in a split plot design with three nitrogen levels $\left(\mathrm{N}_{1}-50 \% \mathrm{RDN}, \mathrm{N}_{2}-100 \% \mathrm{RDN}\right.$ and $\mathrm{N}_{3}-150 \%$ RDN) allocated to main plots and four medium duration rice varieties allocated to sub plots in three replications. The duration of varieties was 135-140 days. The crop was fertilized with recommended dose of $90 \mathrm{~kg} \mathrm{~N}$, $60 \mathrm{~kg} \mathrm{P}_{2} \mathrm{O}_{5}$ and $60 \mathrm{~kg} \mathrm{~K}_{2} \mathrm{O}$ applied through SSP and MOP as a basal application. Nitrogen was applied in the form of urea as per the treatments described in technical programme of work. All agronomic practices and other plant protection measures were followed as and when required. The data on growth parameters, yield attributes and yield as well as economics were recorded and subjected to statistical analysis as per Gomez and Gomez (1984).

\section{Results and Discussion}

\section{Growth parameters}

The statistical analysis resolved that all the growth parameters (Table 1) viz., Plant height, number of tillers per $\mathrm{m}^{2}$, drymatter accumulation were increased with increase in application of nitrogen from $50 \%$ to $150 \%$ RDN. Among medium duration varieties taller plants $(121.2 \mathrm{~cm})$ were noticed with MTU 1001 and shorter plants $(107.8 \mathrm{~cm})$ with MTU 7029 at harvest. More number of tillers $\mathrm{m}^{-2}$ (497) was recorded with MTU 7029, lowest number was recorded (491) with MTU 1153 and it was on par with MTU 1001 and MTU 1075. Maximum drymatter accumulation $\left(13293 \mathrm{~kg} \mathrm{ha}^{-1}\right)$ was recorded with variety MTU 1153 and lowest $\left(11622 \mathrm{~kg} \mathrm{ha}^{-1}\right)$ was recorded with MTU 1001.The interaction effect was found to be non significant with respect to all growth characters. These findings are in conformity with results reported by Bhagel et al., (2013). 


\section{Yield attributes}

Regarding yield attributing characters (Table 2) they are increased with increase in $\mathrm{N}$ application from $50 \%$ to $150 \%$ RDN, whereas, among the medium duration varieties, MTU 1153 recorded highest yield attributing characters and lowest were with MTU 1001. MTU 1153 recorded highest number of panicles $\mathrm{m}^{-2}(310)$, panicle length $(24.42 \mathrm{~cm})$, panicle weight $(3.60 \mathrm{~g})$ and percentage of filled grains panicle ${ }^{-1}(87.77 \%)$ as compared with other varieties. Similar results also reported by Rajput et al., (2016), Shukla et al., (2015) and Pal and Mahunta (2010). Phillip et al., (2012), Reddy and Kulakarni (2007) were reported that significant increase in yield attributes with increase in nitrogen rate from $50 \%$ RDN to $150 \% \mathrm{RDN}$. The grain and straw yields were significantly influenced by both nitrogen levels and medium duration varieties. Irrespective of varieties highest grain yield $\left(5599 \mathrm{~kg} \mathrm{ha}^{-1}\right)$ was recorded with application of $150 \% \mathrm{RDN}$ which was 15.94 and 23.06 per cent more compared to $50 \%$ and $100 \%$ RDN. Similar trend was followed in case of straw yield. Among medium duration varieties, highest grain yield (5558 $\left.\mathrm{kg} \mathrm{ha}^{-1}\right)$ was recorded with variety MTU 1153 and highest straw yield $\left(7044 \mathrm{~kg} \mathrm{ha}^{-1}\right)$ was recorded with variety MTU 7029 which was on par (7037 $\mathrm{kg} \mathrm{ha}^{-1}$ ) with MTU 1153. Whereas, harvest index was not influenced by nitrogen levels but in case of varieties MTU 1153 recorded highest harvest index (44.3\%) over other varieties. Interaction effect between nitrogen levels and varieties was found to be significant with respect to grain and straw yields as reported by Krishna et al., (2015).

Table.1 Influence of nitrogen on growth parameters of medium duration rice varieties

\begin{tabular}{|c|c|c|c|c|c|}
\hline \multirow[t]{2}{*}{ Treatments } & \multirow{2}{*}{$\begin{array}{c}\text { Plant height } \\
(\mathrm{cm})\end{array}$} & \multicolumn{2}{|c|}{$\begin{array}{l}\text { No of tillers } \\
\left(\mathrm{m}^{-2}\right)\end{array}$} & \multicolumn{2}{|c|}{$\begin{array}{l}\text { Drymatter accumulation } \\
\qquad\left(\mathrm{kg} \mathrm{ha}^{-1}\right)\end{array}$} \\
\hline & & $\begin{array}{l}\text { 90 } \\
\text { DAT }\end{array}$ & $\begin{array}{c}\text { At } \\
\text { harvest }\end{array}$ & $\begin{array}{c}\text { 90 } \\
\text { DAT }\end{array}$ & $\begin{array}{c}\text { At } \\
\text { Harvest }\end{array}$ \\
\hline \multicolumn{6}{|c|}{ Nitrogen levels $(\mathrm{N})$} \\
\hline $50 \%$ RDN & 107.9 & 388 & 389 & 10726 & 11182 \\
\hline $100 \%$ RDN & 116.9 & 439 & 442 & 11483 & 12566 \\
\hline $150 \%$ RDN & 120.0 & 491 & 491 & 12352 & 13805 \\
\hline SEm \pm & 2.01 & 13.2 & 13.2 & 191.2 & 333.9 \\
\hline $\mathrm{CD}(\mathbf{P}=\mathbf{0 . 0 5})$ & 8.1 & 52 & 52 & 751 & 1211 \\
\hline \multicolumn{6}{|c|}{$\begin{array}{l}\text { Medium duration rice } \\
\text { varieties }(\mathrm{V})\end{array}$} \\
\hline MTU 1075 & 119.7 & 418 & 421 & 11356 & 12564 \\
\hline MTU 1153 & 111.1 & 419 & 419 & 12206 & 13293 \\
\hline MTU 1001 & 121.2 & 422 & 423 & 10685 & 11622 \\
\hline MTU 7029 & 107.8 & 497 & 497 & 11834 & 12455 \\
\hline SEm \pm & 3.27 & 11.3 & 11.5 & 222.9 & 306.7 \\
\hline $\mathrm{CD}(\mathrm{P}=0.05)$ & 9.7 & 33 & 34 & 662 & 911 \\
\hline \multicolumn{6}{|c|}{ Interaction (NXV) } \\
\hline SEm \pm & 19.8 & 19.5 & 5.68 & 386.2 & 531.2 \\
\hline $\mathrm{CD}(\mathrm{P}=\mathbf{0 . 0 5})$ & NS & NS & NS & NS & NS \\
\hline
\end{tabular}


Table.2 Effect of nitrogen levels on yield attributes of medium duration rice varieties

\begin{tabular}{|c|c|c|c|c|c|c|c|}
\hline Treatments & $\begin{array}{c}\text { Panicles } \\
\left(\mathrm{m}^{-2}\right)\end{array}$ & $\begin{array}{l}\text { Panicle } \\
\text { length } \\
(\mathrm{cm})\end{array}$ & $\begin{array}{c}\text { Test } \\
\text { weight } \\
(\mathrm{g})\end{array}$ & $\begin{array}{l}\text { Percentage of } \\
\text { filled grains } \\
\text { Panicle }^{-1}(\%)\end{array}$ & $\begin{array}{l}\text { Grain } \\
\text { Yield } \\
\left(\mathrm{kg} \mathrm{ha}^{-1}\right)\end{array}$ & $\begin{array}{c}\text { Straw } \\
\text { yield } \\
\left(\mathrm{kg} \mathrm{ha}^{-1}\right)\end{array}$ & $\begin{array}{c}\text { Harvest } \\
\text { index } \\
(\%)\end{array}$ \\
\hline \multicolumn{8}{|l|}{ Nitrogen levels (N) } \\
\hline $\mathbf{5 0 \%}$ RDN & 260 & 23.59 & 22.11 & 72.61 & 4308 & 5923 & 42.2 \\
\hline $100 \%$ RDN & 307 & 23.97 & 21.91 & 82.30 & 5125 & 7023 & 42.1 \\
\hline $150 \%$ RDN & 335 & 23.94 & 21.22 & 87.07 & 5599 & 7597 & 42.4 \\
\hline SEm \pm & 7.02 & 0.23 & 0.39 & 1.44 & 38.9 & 63.9 & 0.37 \\
\hline $\mathrm{CD}(\mathrm{P}=\mathbf{0 . 0 5})$ & 27 & NS & NS & 5.66 & 153 & 251 & NS \\
\hline \multicolumn{8}{|c|}{ Medium duration rice varieties $(\mathrm{V})$} \\
\hline MTU 1075 & 299 & 24.38 & 19.27 & 77.82 & 4915 & 7044 & 41.0 \\
\hline MTU 1153 & 310 & 24.42 & 23.20 & 87.77 & 5558 & 7037 & 44.3 \\
\hline MTU 1001 & 295 & 23.14 & 25.28 & 75.10 & 4483 & 6398 & 41.2 \\
\hline MTU 7029 & 300 & 23.39 & 19.23 & 81.95 & 5087 & 6911 & 42.4 \\
\hline SEm \pm & 7.4 & 0.27 & 0.36 & 1.59 & 86.6 & 97.0 & 0.72 \\
\hline $\mathrm{CD}(\mathrm{P}=\mathbf{0 . 0 5})$ & NS & 0.80 & 1.08 & 4.70 & 257 & 288 & 2.1 \\
\hline \multicolumn{8}{|l|}{ Interaction(NXV) } \\
\hline SEm \pm & 12.8 & 0.47 & 0.62 & 2.74 & 150.0 & 168.1 & 1.24 \\
\hline $\mathrm{CD}(\mathbf{P}=\mathbf{0 . 0 5})$ & NS & NS & NS & NS & 446 & 499 & NS \\
\hline
\end{tabular}

Table.3 Economics of medium duration rice varieties as influenced by nitrogen levels

\begin{tabular}{|c|c|c|c|}
\hline Treatments & $\begin{array}{c}\text { Cost of } \\
\text { cultivation } \\
\left(\text { Rs. ha }{ }^{-1}\right) \\
\end{array}$ & $\begin{array}{l}\text { Net returns } \\
\left(\text { Rs. ha } \mathbf{h}^{-1}\right)\end{array}$ & $\begin{array}{l}\text { Returns per rupee } \\
\text { investment }\end{array}$ \\
\hline Nitrogen levels $(\mathbf{N})$ & $28074 \quad 45074$ & & 2.63 \\
\hline $50 \% \mathrm{RDN}$ & 30634 & 58328 & 2.90 \\
\hline $100 \% \mathrm{RDN}$ & 32194 & 63385 & 2.97 \\
\hline $150 \% \mathrm{RDN}$ & - & 367.5 & 0.012 \\
\hline SEm \pm & - & 1143 & 0.04 \\
\hline \multicolumn{4}{|l|}{$\mathrm{CD}(\mathrm{P}=0.05)$} \\
\hline \multicolumn{4}{|c|}{ Medium duration rice varieties $(\mathrm{V})$} \\
\hline MTU 1075 & 30301 & 54728 & 2.80 \\
\hline MTU 1153 & 30301 & 63609 & 3.07 \\
\hline MTU 1001 & 30301 & 47169 & 2.55 \\
\hline MTU 7029 & 30301 & 58257 & 2.92 \\
\hline SEm \pm & - & 1021.2 & 0.033 \\
\hline $\mathrm{CD}(\mathrm{P}=0.05)$ & - & 3034 & 0.10 \\
\hline \multicolumn{4}{|l|}{ Interaction (NXV) } \\
\hline SEm \pm & - & 1769 & 0.059 \\
\hline $\mathrm{CD}(\mathrm{P}=0.05)$ & - & 5256 & 0.17 \\
\hline
\end{tabular}




\section{Economics}

Perusal data on economics (Table 3) indicated that the gross returns, net returns and return per rupee investment was significantly influenced by both nitrogen levels and medium duration varieties and their interaction. Application of $150 \%$ RDN (Rs. $\left.63385 \mathrm{ha}^{-1}, 2.97\right)$ to the variety MTU 1153 (Rs. $63069 \mathrm{ha}^{-1}$, 3.07) recorded highest net returns and return per rupee investment due to highest grain and straw yields respectively over the other varieties tested in the experiment. Similar results were also reported by Santhosh Kumar et al., (2013).

\section{References}

Anonymous. 2016. Department of Agriculture, Cooperation \& Farmer's Welfare. Directorate of Economics \& Statistics, New Delhi.

Baghel, J.K., Singh, Y.V., Kumar, D., Abraham, G and Sanjay, S. 2013. Effect of varieties and nitrogen management on nematodes infestation and productivity of aerobic rice (Oryza sativa). Indian Journal of Agronomy. 58(3): 427-429.

Gomez, A.K. and Gomez, A.A. 1984. Statistical procedures for Agricultural Research. International Rice Research Institute Book. International Science Publication. John Wiley and Sons, Singapore.

Krishna, R.Y., Gopala Swamy, S.V.S and Ramana, M.V. 2015. Influence of Plant densities and nitrogen levels on yield of transplanted rice. The Andhra Agricultural Journal. 62(2): 384-387.

Pal, A.K and Mahunta, R. 2010. Effect of age of seedling and application of nitrogen on wet season rice. Oryza. 47(3): 254256.

Philiip, P., Ghirish, J., Pushpraj, S and Smita, S. 2012. Effect of different nitrogen levels on newly developed rice varieties under transplanted condition. Agricultural Science Digest 32(1): 7578.

Prasad, M and Prasad, R. 1980. Yield and nitrogen uptake by rice as affected by variety, method of planting and new nitrogen fertilizers. Fertilizer Research. 1(4): 207-213.

Punaullah, G.M., Saleque, M.A., Abedin, M.J and Ishaque, M. 1998. Integrated nutrient management with inorganic fertilizers, crop residues and organic manures for wheat- mungbean- T. aman rice cropping pattern. Programme of national workshop on integrated nutrient management for crop production and soil fertility. BARI: 171182.

Rajuput, A., Rajput, S.S and Girish, J. 2016. Performance of rice varieties grown under different spacings with planting depths in system of rice intensification. International Journal of Agriculture, Environment and Biotechnology. 9(5): 833-838.

Reddy, S.C and Kulkarni, B.S. 2007. Effect of varieties and seeding density on the productivity of direct sown rice. Journal of Research ANGRAU. 35(4): 13-18.

Santhosh Kumar, G., Srinivas Raju, M and Mahendra Kumar, R. 2013. Production potentialities of rice genotypes as influenced by nitrogen levels. Indian Journal of Agricultural Research, 47(2): 169-172.

Shukla ,V.K., Tiwari R.K., Malviya D.K., Singh, S.K and Ram, U.S. 2015. Performance of rice varieties in relation to nitrogen levels under irrigated condition. African Journal of Agricultural Research. 10(12): 15171520.

Siddiq, S., Anayat, A., Sattar, A., Ali, A.M and Yaseen, M. 2011. Response of different rice (Oryza sativa L.) cultivars 
to different NPK levels in the central cropping zone of Punjab. Agricultural Science Digest. 31(3): 155-160.

Singh, R.K and Nemado, K.N. 2004. Effect of fertility levels and herbicides on growth, yield and nutrient uptake of directseeded rice (Oryza sativa L.). Indian Journal of Agronomy. 49(1): 34-36.

\section{How to cite this article:}

Sivaleela, S., Manukonda Srinivas, Ch. Pulla Rao and Sireesha, A. 2018. Influence of Nitrogen on Economics of Medium duration Rice Varieties. Int.J.Curr.Microbiol.App.Sci. 7(12): 915920. doi: https://doi.org/10.20546/ijcmas.2018.712.114 